\title{
Nutritional quality of a freshwater heterotrophic flagellate: trophic upgrading of its microalgal diet for Daphnia hyalina
}

\author{
Alexandre Bec ${ }^{1,2, *}$, Christian Desvilettes ${ }^{1}$, Aurélie Véra ${ }^{1}$, Charles Lemarchand ${ }^{1}$, \\ Dominique Fontvieille ${ }^{2}$, Gilles Bourdier ${ }^{1}$ \\ ${ }^{1}$ Laboratoire de Biologie des Protistes, UMR CNRS 6023, Université Blaise Pascal, 63177 Aubière cedex, France \\ ${ }^{2}$ CARRTEL, Université de Savoie, 73376 Le Bourget du Lac cedex, France
}

\begin{abstract}
Bacterivorous freshwater heterotrophic flagellates seem to be too poor in (n-3) series polyunsaturated fatty acids (PUFA) to be able to sustain major zooplankton growth by themselves. This study shows that when the heterotrophic flagellate Aulacomonas submarina fed on microalgae, either Rhodomonas lacustris (Aulacomonas/R.) or Chlorogonium elongatum (Aulacomonas/C.), this species exhibited (n-3) series PUFA in great quantities. Therefore, A. submarina PUFA composition seems to depend mainly on its algal diet. However, the biosynthetic capacities of $A$. submarina seem to have endowed it with greater amounts of 20 PUFA and a more diversified PUFA composition. Moreover, this study also shows that Daphnia hyalina exhibits a higher fecundity when fed on Aulacomonas/C. (or Aulacomonas/R.) than is the case when fed on $C$. elongatum (or respectively $R$. lacustris). This suggests that the ability of $A$. submarina to convert dietary lipids results in the biochemical value of its food source being upgraded.
\end{abstract}

KEY WORDS: Heterotrophic nanoflagellates · Nutritional quality $\cdot$ Fatty acids $\cdot$ PUFA

Resale or republication not permitted without written consent of the publisher

Numerous studies devoted to the functioning of the microbial loop in marine or lacustrian environments have shown the key role of protozoans in transferring organic matter from small size particules to higher trophic levels (Sherr \& Sherr 1988, Gifford 1991).

Among these protozoans, heterotrophic nanoflagellates (HNF) exhibit sizes and at times relatively great abundance, which render them important prey for zooplanktonic microcrustacea (Sanders \& Wickham 1993, Laybourn Parry 2000). Nonetheless, it has been shown that although zooplankton predation rates on HNF are often high, this does not assure that HNF can be a high quality food (Sanders et al. 1996). Indeed, morphology and movement influence the grazing efficiency of zooplankton whereas the biochemical composition of the food determines its nutritive value (Ahlgren et al. 1990 Mayzaud et al. 1998).

In natural environments, sestonic phosphorus (Elser et al. 2001, Makino et al. 2002) and specific lipid compounds (Arts 1998, Müller-Navarra et al. 2000) can be dependable predictors of food quality for zooplankton. In the same way, ciliates and HNF have a high incorporation of P (Caron \& Goldman 1990) and thus may be a particularly important source of phosphorus-containing compounds for zooplankton. Nevertheless, mineral content alone is insufficient to predict food quality (Anderson \& Hessen 1995, Müller-Navarra 1995) and it has been suggested that essential food compounds, especially (n-3) series polyunsaturated fatty acids (PUFA), play a significant role (Wacker \& Von Elert 2001).

Compared with microalgae, lipid and fatty acid composition of freshwater HNF have attracted less attention (Desvilettes et al. 1997). However, recent work by Véra et al. (2001) showed that typical aquatic HNF, such as Spumella and Paraphysomonas, have little capacity for synthesizing (n-3) series PUFA and exhibit fatty acid profiles strongly influenced by their food. Futhermore, when fed on bacteria, these HNF species lack (n-3) PUFA as bacteria generally do not produce PUFA (Napolitano 1998). Thus, it is possible that freshwater algivorous flagellates exhibit (n-3) series PUFA in much greater quantities than the bacterivorous ones do. Indeed, in marine environments, it has been suggested that algivorous protozoans contain (n-3) series PUFA in great amounts (Claustre et al. 1989). Moreover, Klein Bretteler et al. (1999) suggested that, as protozoans may produce new compounds, they upgrade the biochemical composition of food rather than merely repackage it. In this context, we therefore initially compared the PUFA compositions of the 
algivorous flagellate Aulacomonas submarina to PUFA compositions of 2 types of algal food, the Cryptophycea Rhodomonas lacustris and the Chlorophycea Chlorogonium elongatum. We then investigated whether the addition of $A$. submarina as a trophic intermediate in the simplified nanoplanktonic microalga-zooplankton food chain affected cladoceran development and reproduction. With a view to this, we conducted growth experiments on Daphnia hyalina fed 4 different diets: (1) A. submarina fed on $R$. lacustris; (2) A. submarina fed on C. elongatum; (3) R. lacustris; or (4) C. elongatum in order to compare their nutritional value for the cladoceran.

Material and methods. Protists cultures: The different protists were obtained from our own laboratory collection. The autotrophic flagellates, Rhodomonas lacustris (12 $\mathrm{m}$ long) and Chlorogonium elongatum (18 $\mathrm{um}$ long) were mass cultivated in a modified Synura medium (Véra et al. 2001). These cultures were grown semi-continuously at $20^{\circ} \mathrm{C}$ under a $12: 12 \mathrm{~h}$ light:dark photoperiod. In order to maintain an exponential growth rate, 20 to $40 \%$ of the medium was renewed every other day. The algivorous flagellate Aulacomonas submarina (10 to $30 \mu \mathrm{m}$ long) was grown in $800 \mathrm{ml}$ of Synura medium to which $100 \mathrm{ml}$ of $R$. lacustris culture or $C$. elongatum culture was added daily. Each culture was conducted in triplicate.

Zooplankton culture: Daphnia hyalina was isolated from zooplankton samples collected in Lake Annecy,

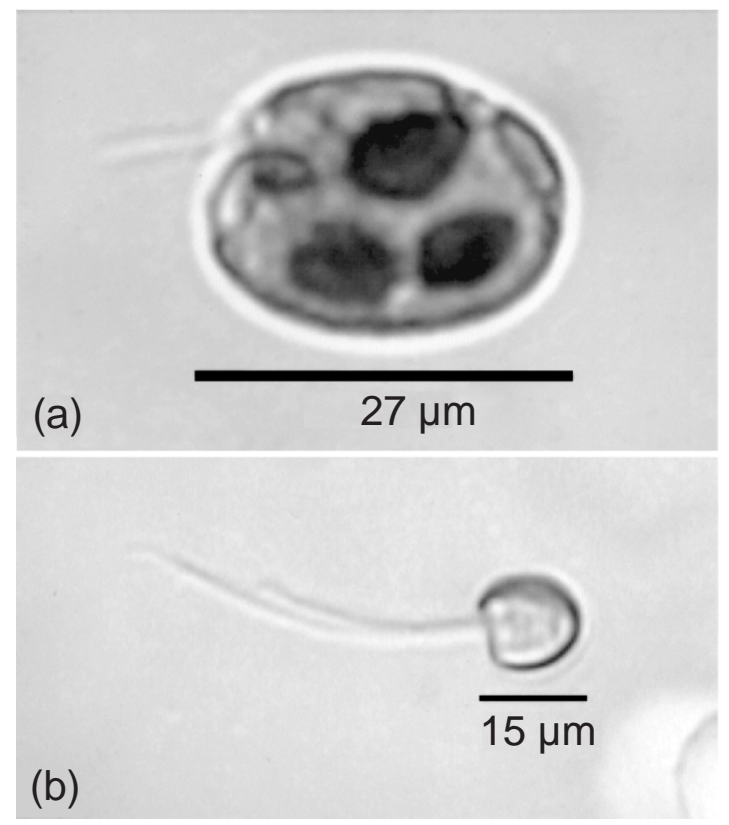

Fig. 1. (a) Live cell of Aulacomonas submarina fed on Rhodomonas lacustris before starvation. (b) Live cell of $A$. submarina after starvation. Note that the cell biovolume is reduced and that digestion vacuoles have disappeared
France, and cultured in spring water, and fed every other day with a 50/50 mixture of freeze-dried fish foods (Tetramin ${ }^{\circledR}+$ Tetraphyll $^{\oplus}$ ) broken down into fine particles by ultrasound.

Growth experiment: Twelve $600 \mathrm{ml}$ glass tanks were filled with spring water. Each tank received 50 newly hatched Daphnia hyalina ( $<12 \mathrm{~h}$ old). For $10 \mathrm{~d}$, triplicates of $50 \mathrm{D}$. hyalina each were fed daily with Rhodomonas lacustris cells, Aulacomonas submarina cells grown on $R$. lacustris (Aulacomonas/R.), Chlorogonium elongatum cells and $A$. submarina cells grown on C. elongatum (Aulacomonas/C.). This experiment was conducted at $20^{\circ} \mathrm{C}$ under a 12:12 h light:dark cycle and food concentration was $1.5 \times 10^{4} \mathrm{cells} \mathrm{ml}^{-1}$. Thus, the cladocerans in each treatment were not limited by food quantity. At the end of the survey, D. hyalina survival, $D$. hyalina length and egg number per female were recorded.

Statistical analysis: The survival rate, the length and the fecundity of the cladocerans at the end of each experiment were compared 2-by-2 with a 1-way ANOVA (Scheffé test) $(\mathrm{p}<0.01)$.

Sampling and fatty acid analysis: Microalgae and Aulacomonas submarina were recovered by filtration on precombusted GF/F glass-fiber filters. Before filtration or Daphnia hyalina feeding, A. submarina cells in culture were starved for $36 \mathrm{~h}$ in the dark. This treatment reduced the size of the cell to around 10 to $15 \mu \mathrm{m}$ in length, caused the digestion vacuoles to disappear (see Fig. 1) and allowed us to check that no residual Rhodomonas lacustris or Chlorogonium elongatum were present in the culture. Fatty acid analyses were performed on samples ( 3 aliquots of different flasks) of food algae and A. submarina. After extraction and derivatization, fatty acids were identified by gas chromatography. A full description of the methodology used was given previously by Véra et al. (2001).

Results and discussion. Changes in PUFA composition of Aulacomonas submarina in response to diets (Figs. 2 \& 3): Rhodomonas lacustris, like other autotrophic cryptomonads, was characterized by high percentages of 18:4(n-3) and 20:5(n-3), whereas Chlorogonium elongatum exhibited a different PUFA composition dominated by $16: 4(n-3)$ and $18: 3(n-3)$, both typical of Chlorophyceae PUFA (Sargent et al. 1995). As shown in Figs. 2 \& 3, these microalgae had a marked influence on the PUFA composition of $A$. submarina. The PUFA content of starved $A$. submarina was strongly dominated by the $(n-3)$ series, which is not the case for bacterivorous HNF, for which (n-6) fatty acid series constitute the main PUFAs (Desvilettes et al. 1997, Véra et al. 2001). As shown in Figs. 2 \& 3, the PUFA composition of Aulacomonas/C. differs from that of Aulacomonas/R. as Aulacomonas/C. had fewer 20 (n-3) series PUFA characteristic of cryptomonads 


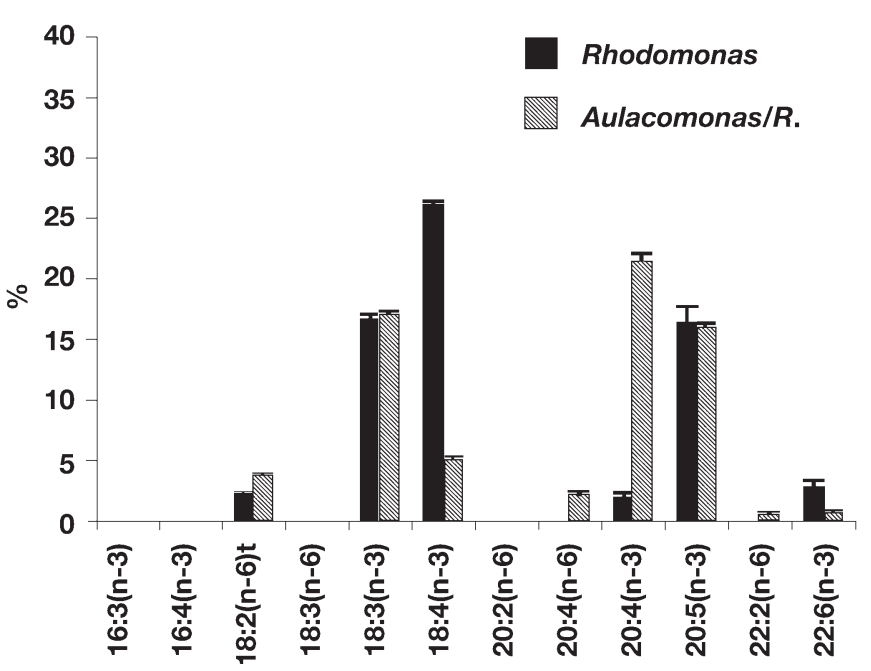

Fig. 2. Polyunsaturated fatty acid compositions (wt \% of total fatty acids) of Rhodomonas lacustris and Aulacomonas submarina fed on R. lacustris (Aulacomonas/R.)

and more 16 (n-3) series PUFA characteristic of Chlorophyceae. Likewise, Klein Breteler et al. (1999) showed that the heterotrophic dinoflagellate Oxyrrhis marina fed on the Chlorophyceae Dunaliella sp. (Oxyrrhis/D.) also contained 16 (n-3) series PUFA. However, it should be noted that $A$. submarina lipid analyses were performed after a period of starvation, which caused the digestion vacuoles to disappear. This allowed us to hypothesize that these typical algal PUFA had become part of A. submarina lipids.

Comparison of the PUFA composition of Aulacomonas submarina and its food sources seems to suggest that it is able to bioconvert fatty acid. Indeed, Aulacomonas/R., in contrast to Rhodomonas lacustris, contains inverse proportions of 20:4(n-3) and 18:4(n-3), and Aulacomonas/C., in contrast to Chlorogonium elongatum, has 20:4(n-3) and 20:5(n-3) in significant quantities. Similarly, Klein Breteler et al. (1999)

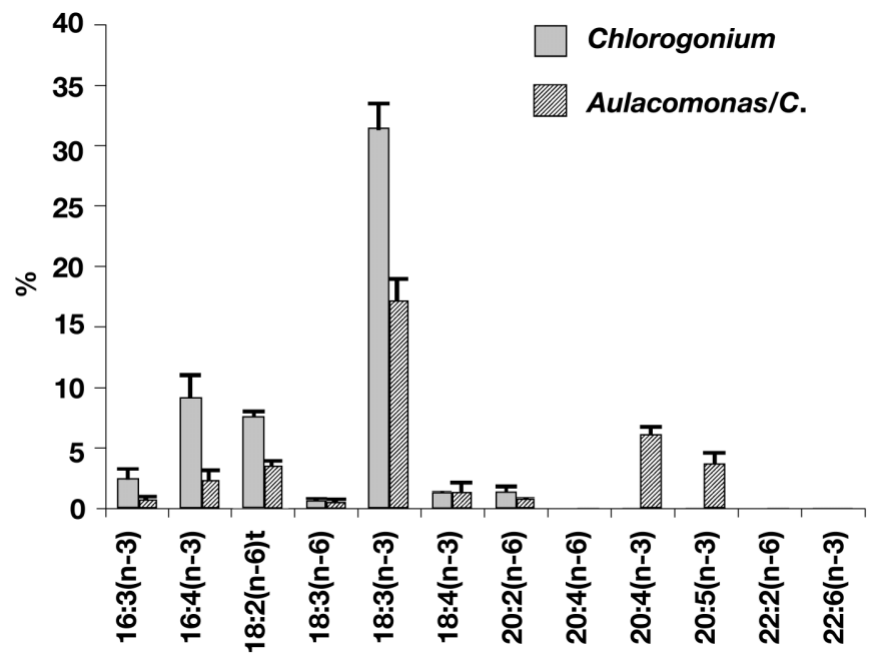

Fig. 3. Polyunsaturated fatty acid compositions (wt \% of total fatty acids) of Chlorogonium elongatum and Aulacomonas submarina fed on C. elongatum (Aulacomonas/C.)

reported that, unlike Dunaliella sp., Oxyrrhis/D. exhibited long chain PUFA like 22:6(n-3). A. submarina, therefore, seems to convert PUFA from its food into long carbon chain PUFA through a process of elongation and desaturation. In Aulacomonas/R., dietary 18:4(n-3) was probably elongated into 20:4 (n-3) and in Aulacomonas/C., dietary 18:3(n-3) seemed to be partially bioconverted into 20:4(n-3) and finally into 20:5(n-3) by means of $\Delta 6$ and $\Delta 5$ desaturases. As this algivorous flagellate is a protista incertae sedis distantly related to heterokont flagellates (Brugerolle \& Patterson 1990) and does not contain any residual plast, unlike a number of freshwater genera (Spumella, Paraphysomonas, Polytoma; Arndt et al. 2000), these desaturases are probably located in endoplasmic reticulum, as observed for ciliates.

Finally, even if dietary PUFA have a marked influence on Aulacomonas submarina lipid composition,

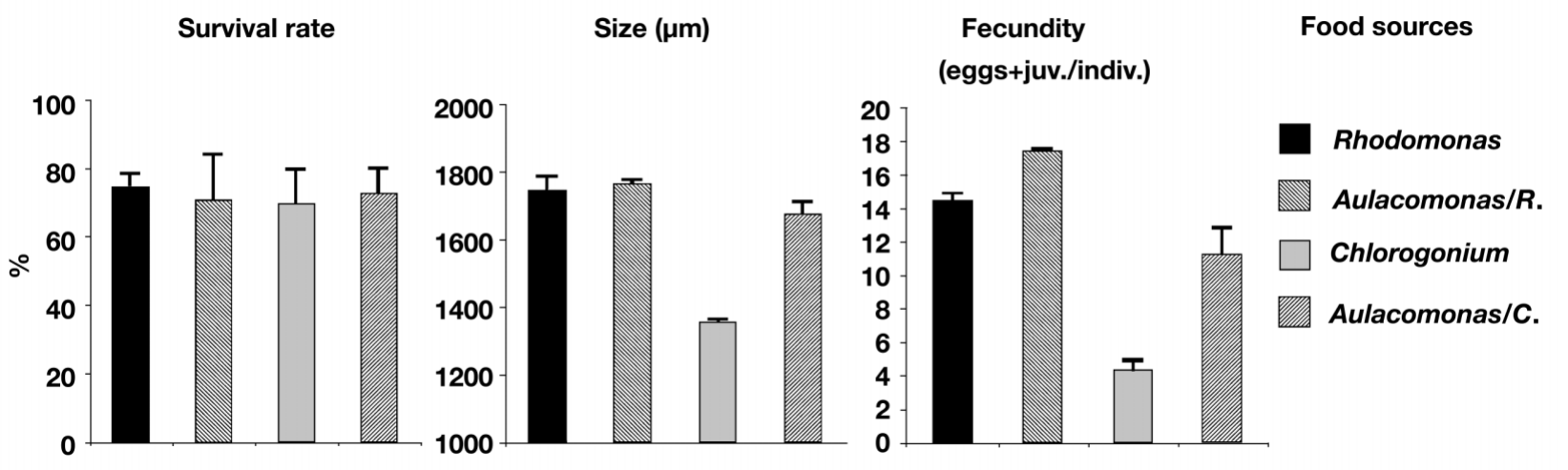

Fig. 4. Survival rate, size and fecundity of Daphnia hyalina fed on Rhodomonas lacustris, Aulacomonas/R., Chlorogonium elongatum and Aulacomonas/C. 
this PUFA bioconversion results in Aulacomonas/R. and Aulacomonas/C. having high amounts of both $20: 4(n-3)$ and 20:5(n-3). It is worth noting that the ratios of the percentages of 18:4(n-3):20:4(n-3) and 18:4(n-3): 20:5(n-3) calculated for Aulacomonas/R. (i.e. 0.22 and 0.30 respectively) are equivalent to those calculated in Aulacomonas/C. (i.e. 0.21 and 0.35 respectively). Thus, this PUFA bioconversion seems to play an important role (changes in cellular membrane conformation?) which needs further investigation.

Nutritional quality of Aulacomonas submarina and the different food sources: The different food sources all allowed the development and reproduction of Daphnia hyalina (Fig. 4). The survival rates measured for the 4 treatments were not significantly different $(\mathrm{p}<0.01)$. However, the size and fecundity of the cladocerans fed on Chlorogonium elongatum were distinctly low. It is also interesting to note that the presence of neonates or juveniles were not recorded in the C. elongatum treatment, which shows that cladocerans fed on $C$. elongatum develop more slowly. Moreover, the fecundity recorded in the Aulacomonas/R. treatment was significantly the highest $(\mathrm{p}<0.01)$. Thus, these results show that $A$. submarina is of better nutritional quality for $D$. hyalina than the microalga it feeds on. Similarly, recent studies have also suggested that protozoans may improve the food quality for marine copepods by acting as intermediate prey (Klein Breteler et al. 1999, Tang et al. 2001).

In view of the similar morphological characteristics (size, mobility) of the microalgae and the heterotrophic flagellate tested, their biochemical composition may be the main factor influencing their food quality. Thus, the low nutritional value of Chlorogonium elongatum, like that of Chlorophyceae in general, seems to be most often connected with a lack of 20:5(n-3) (Ahlgren et al. 1990, Brett \& Müller-Navarra 1997). In contrast, Aulacomonas/C. could have supplied the cladocerans with important quantities of 20 PUFA notably of 20:5(n-3). The elongation and desaturation capacities of the heterotrophic flagellate therefore seem to explain why Aulacomonas/C. is of better nutritional value than C. elongatum alone. The addition of $A$. submarina as an intermediate in the Rhodomonas lacustris-Daphnia hyalina simplified trophic chain had less influence on the development of the cladocerans than had been previously assumed (Fig. 4). Nevertheless it should be recalled that Cryptophyceae are recognised as already being of high nutritional value due to their high 20:5(n-3) contents (Ahlgren et al. 1990). However, Aulacomonas/R. could provide more diversified specific compounds than $R$. lacustris alone, notably specific sterols (Klein Breteler et al. 1999). These latter compounds must be taken into account for determining the quality of zooplankton food (Von Elert \& Wolffrom 2001).
Conclusion. Generally speaking, the essential compound contents of protozoans (here fatty acids) depend on the synthetic capacities peculiar to each species but above all on the biochemical composition of the food available. The considerable variations in the biochemical composition of heterotrophic flagellates which may ensue largely explain the extreme variability of their own nutritional value, as observed by Sanders \& Wickham (1993). Strictly from the point of view of (n-3) series PUFA contents, free HNF fed on bacteria do not seem to constitute a high quality food (Véra et al. 2001); it seems on the other hand that flagellates able to ingest microalgae are of much better quality. This study shows that an algivorous flagellate, such as Aulacomonas submarina, accumulates and also modifies the dietary PUFA and by doing so can upgrade the nutritional value of its algal food source.

Finally, as heterotrophic flagellates are generally considered as the major consumers of autotrophic picoplanktonic species (Weisse 1993, Dolan \& Šimek 1998) mainly composed of picocyanobacteria and picochlorophyceae poor in 20 PUFA, trophic upgrading of autotrophic picoplankton food quality by heterotrophic flagellates can become an important source of essential compounds for zooplankton. This may prove to be a key process in the functioning of aquatic ecosystems whose importance remains to be specified.

\section{LITERATURE CITED}

Ahlgren G, Lundstedt L, Brett M, Forsberg C (1990) Lipid composition and food quality of some freshwater phytoplankton for cladoceran zooplankters. J Plankton Res 12: 809-818

Anderson TR, Hessen DO (1995) Carbon or nitrogen limitation in marine copepods? J Plankton Res 17:317-331

Arndt H, Dietrich D, Auer B, Cleven EJ, Gräfenham T, Weitere M, Mylnikov AJ (2000) Functional diversity of heterotrophic flagellates in aquatic ecosystems. In: Leadbeater BSC, Green JC (eds) The flagellates, unity diversity and evolution. Taylor \& Francis, London, p 240-269

Arts MT (1998) Lipids in freshwater zooplankton selected ecological and physiological aspects. In: Arts MT, Wainman BC (eds) Lipids in freshwater ecosystems. SpringerVerlag, New York, p 71-86

Brett MT, Müller-Navarra DC (1997) The role of highly unsaturated fatty acids in aquatic food web processes. Freshw Biol 38:483-500

Brugerolle G, Patterson DJ (1990) A cytological study of Aulacomonas submarina Skuja 1939, a heterotrophic flagellate with a novel ultrastructural identity. Eur J Protistol 25: 191-199

Caron DA, Goldman JC (1990) Protozoan nutrient regeneration. In: Capriulo GM (ed) Ecology of marine protozoa. Oxford University Press, New York, p 283-306

Claustre H, Marty JC, Cassiani L, Dagaut J (1989) Fatty acid dynamics in phytoplankton and microzooplankton communities during a spring bloom in the coastal Ligurian sea: ecological implications. Mar Microb Food Webs 3:51-66

Desvilettes C, Bourdier G, Amblard C, Barth B (1997) Use of 
fatty acids for the assessment of zooplankton grazing on bacteria, protozoans and microalgae. Freshw Biol 38: $629-637$

Dolan JR, Šimek K (1998) Ingestion and digestion of an autotrophic picoplankter, Synechococcus, by a heterotrophic nanoflagellate, Bodo saltans. Limnol Oceanogr 43: $1740-1746$

Elser JJ, Hayakawa K, Urabe J (2001) Nutrient limitation reduces food quality for zooplankton: Daphnia response to seston phosphorus enrichment. Ecology 82:898-903

Gifford DJ (1991) The protozoan-metazoan trophic link in pelagic ecosystems. J Protozool 38:81-86

Harvey HR, Ederington MC, McManus GB (1997) Lipid composition of the marine ciliates Pleuronema sp. and Fabrea salina: shifts in response to change diets. J Eukaryot Microbiol 44:189-193

Klein Breteler WCM, Schogt N, Baas M, Schouten S, Kraay GW (1999) Trophic upgrading of food quality by protozoans enhancing copepod growth: role of essential lipids. Mar Biol 135:191-198

Laybourn Parry J (2000) Flagellates and the microbial loop. In: Leadbeater BSG, Green JC (eds) The flagellates, unity diversity and evolution. Taylor \& Francis, London, p 216-240

Makino W, Urabe J, Elser JJ, Yoshimizu C (2002) Evidence of phosphorus-limited individual and population growth of Daphnia in a Canadian Shield lake. Oïkos 97:197-205

Mayzaud P, Tirelli V, Bernard JM, Roche-Mayzaud O (1998) The influence of food quality on the nutritional acclimatation of the copepod Acartia clausi. J Mar Syst 15: 483-493

Müller-Navarra DC (1995) Evidence that a highly unsaturated fatty acid limits Daphnia growth in nature. Arch Hydrobiol 132:297-307

Müller-Navarra DC, Brett MT, Liston AM, Goldman CR (2000) A highly unsaturated fatty acid predicts carbon

Editorial responsibility: John Dolan, Villefranche-sur-Mer, France transfer between primary producers and consumers. Nature 403:74-77

Napolitano GE (1998) Fatty acids as trophic and chemical markers. In: Arts MT, Wainman BC (eds) Lipids in freshwater ecosystems. Springer-Verlag, New York, p 21-44

Sanders RW, Wickham SA (1993) Planktonic protozoa and metazoa: predation, food quality and population control. Mar Microb Food Webs 7:197-223

Sanders RW, Williamson CE, Stutsman PL, Moeller RE, Goulden CE, Aoki-Goldsmith R (1996) Reproductive success of 'herbivorous' zooplankton fed algal and non algal food resources. Limnol Oceanogr 41:1295- 1305

Sargent JR, Bell MV, Henderson RJ (1995) Protists as source of (n-3) polyunsaturated fatty acids for vertebrate development. In: Brugerolle G, Mignot JP (eds) Protistological actualities. Proc 2nd Eur Congr Protistol. Université Blaise Pascal, Clermont-Ferrand, p 54-64

Sherr EB, Sherr BF (1988) Role of microbes in pelagic food webs: a revised concept. Limnol Oceanogr 33:1225-1227

Tang KW, Jakobsen HH ,Visser AW (2001) Phaeocystis globosa (Prymnesiophyceae) and the planktonic food web: feeding, growth, and trophic interactions among grazers. Limnol Oceanogr 46:1860-1870

Véra A, Desvilettes C, Bec A, Bourdier G (2001) Fatty acid composition of freshwater heterotrophic flagellates: an experimental study. Aquat Microb Ecol 25:271-279

Von Elert E, Wolffrom T (2001) Supplementation of cyanobacterial food with polyunsaturated fatty acids does not improve growth of Daphnia. Limnol Oceanogr 46: 1552-1558

Wacker A, Von Elert E (2001) Polyunsaturated fatty acids: evidence for non-substitutable biochemical resources in Daphnia galeata. Ecology 82:2507-2520

Weisse T (1993) Dynamics of autotrophic picoplankton in marine and freshwater ecosystems. Adv Microb Ecol 13: $327-369$

Submitted: October 4, 2002; Accepted: January 23, 2003

Proofs received from author(s): April 28, 2003 